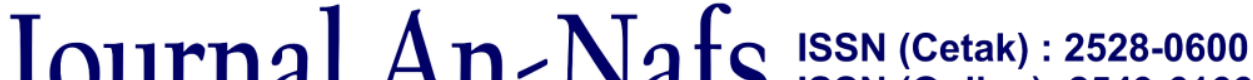 ISSN (Online): 2549-6166 \\ Kajian Penelitian Psikalogi
}

https://ejournal.iai-tribakti.ac.id/index.php/psikologi

https://doi.org/10.33367/psi.v6i2.1465

\section{Pelatihan Emotional Intelligence untuk Meningkatkan Kemampuan Manajemen Konflik Pada Siswa SMA}

\author{
Natasha Gandhi ${ }^{*}$, Putu Hening Wedanthi ${ }^{2}$, Setyani Alfinuha ${ }^{3}$ \\ Universitas Surabaya \\ 1'eugenia.gandhi@gmail.com, ${ }^{2}$ putuheningwedanthi@gmail.com, ${ }^{3}$ setyanialfinuha@gmail.com \\ *Correspondence
}

\section{Article Information:}

Received 17 November 2020

Revised 04 October 2021

Accepted 05 October 2021

Keywords:

emotional intelligence; conflict management; adolescent

\section{Kata Kunci:}

kecerdasan emosi; manajemen konflik; remaja

\section{Abstract}

The purpose of this study was to see the effectiveness of emotional intelligence training in helping subjects overcome the conflict they were experiencing. Conflict is a situation where each other conflicts with each other. In the organisation's scope, namely the Student Council, conflict refers to disagreements between people or members of the Student Council. Improper application of conflict management can lead to unsanitary working conditions. It shows the importance of the intervention given to manage conflict, especially in the Student Council, which is through emotional intelligence training. The research design used was experimental (one group pretest-posttest) with 19 subjects (15-18 years). The training consisted of six sessions and was conducted over two days. The results obtained from this study were that there was a significant increase and change in the integrating type $(\mathrm{p}=0.027, \mathrm{p}<0.05)$ and compromising $(\mathrm{p}=$ $0.021, \mathrm{p}<0.05)$. While the other types, namely domination, avoiding, and obliging, did not experience significant changes. Through emotional intelligence training, participants will learn how to control emotions so that when faced with problems, participants can use appropriate conflict management to solve these problems.

Tujuan dari penelitian ini adalah melihat efektifitas pelatihan emotional intelligence dalam membantu subjek mengatasi konflik yang sedang dialami. Konflik yaitu sebuah keadaan di mana antara satu sama lain saling bertentangan. Pada ruang lingkup organisasi yakni OSIS, konflik mengacu pada ketidaksepakatan antara orang atau anggota OSIS. Ketidaktepatan penerapan manajemen konflik dapat menyebabkan kondisi kerja yang kurang sehat. Hal ini menunjukkan pentingnya intervensi yang diberikan untuk mengelola konflik khususnya dalam OSIS, salah satunya melalui pelatihan emotional intelligence. Desain penelitian yang digunakan ialah eksperimen (one group pretest posttest) dengan subjek berjumlah 19 orang ( 15 - 18 tahun). Pelatihan ini terdiri dari enam sesi dan dilakukan dalam waktu dua hari. Hasil yang didapatkan dari penelitian ini ialah terdapat peningkatan serta perubahan yang signifikan pada tipe integrating $(\mathrm{p}=0.027$, $\mathrm{p}<0.05)$ dan compromising $(\mathrm{p}=0.021, \mathrm{p}<0.05)$. Sedangkan pada 
tipe lainnya yakni dominationg, avoiding dan obliging tidak mengalami perubahan yang signifikan. Melalui pelatihan emotional intelligence, peserta akan dapat belajar cara mengendalikan emosi sehingga pada saat berhadapan dengan permasalahan, peserta dapat menggunakan manajemen konflik yang tepat untuk menyelesaikan permasalahan tersebut.

\section{PENDAHULUAN}

Masa remaja mengacu pada periode yang menandai proses transisi dari masa kanak-kanak ke dewasa. Secara historis, hal ini biasanya terjadi antara usia 12 hingga 18 tahun yang dimulai sejak permulaan masa pubertas (perubahan hormon) hingga proses independensi dari wali (matang secara hukum). Pada masa ini, seseorang sudah mulai dikaitkan dengan proses pengambilan keputusan atau pengambilan resiko serta telah terjadi peningkatan reaktifitas emosional (Jaworska \& MacQueen, 2015).

Masa remaja juga bertepatan dengan terjadinya perubahan dalam lingkungan sosial dan sekolah seperti menghabiskan lebih banyak waktu dengan teman sebaya, serta terjadi peningkatan otonomi pada diri individu. Perubahan perilaku ini terjadi dalam konteks perubahan perkembangan yang dipengaruhi oleh faktor lingkungan eksternal dan internal berpotensi menimbulkan konflik pada diri remaja, baik konflik yang bersifat intraindividu maupun interindividu.

Remaja juga kerap mengalami permasalahan baik permasalahan yang bersifat pribadi maupun sosial. Pada konteks pribadi misalnya konflik dirinya dengan berbagai perubahan yang terjadi dengan tugas-tugas perkembangan sedangkan konflik sosial misalnya saat berada dalam sebuah organisasi. Disetiap sekolah banyak terdapat organisasi yang berbeda salah satunya adalah organisasi siswa intrasekolah (OSIS). Organisasi ini juga yang menjadi tempat potensial terjadinya konflik sosial.

Konflik sendiri yaitu sebuah keadaan di mana antara satu sama lain saling bertentangan. Pada ruang lingkup organisasi, konflik mengacu pada ketidaksepakatan antara orang atau anggota organisasi. Ketidaksepakatan tersebut dapat terjadi antara semua manusia. Konflik dapat dibagi menjadi lima macam, antara lain adalah konflik interpersonal, konflik intrapersonal, konflik antar kelompok, konflik intrakelompok dan konflik intraorganisasi (Thakore, 2013).

Pada penelitian ini akan dibahas tentang konteks konflik dalam lingkungan organisasi yaitu OSIS. Berdasarkan hasil wawancara awal terhadap pembimbing serta 10 anggota OSIS SMA menunjukkan beberapa masalah yang muncul seperti tidak mampu menerima pendapat dari orang lain, membawa permasalahan internal kedalam kehidupan sehari-hari, cenderung pasif sehingga bergantung pada teman-teman yang lain. Kondisi tersebut menunjukkan bahwa remaja anggota OSIS di SMA kurang mampu mengelola konflik dalam organisasi dengan baik sehingga perilaku yang muncul adalah penyelesaikan konflik yang kurang adaptif. Padahal pengelolaan konflik atau manajemen konflik sangat diperlukan khususnya dalam menjalankan sebuah organisasi seperti OSIS agar dapat mengatasi konflik yang ada dengan cara yang tepat. 
Manajemen konflik merupakan strategi atau cara yang yang dilakukan oleh pihakpihak yang berkonflik ataupun melibatkan intervensi dari luar. Tujuan dari manajemen konflik ini adalah untuk mempengaruhi situasi konflik sehingga muncul komponenkomponen konstruktif dalam prosesnya serta dapat membantu para pihak yang berkonflik untuk menemukan jalan keluar atas permasalahan yang dihadapi. Manajemen konflik dikatakan berhasil bila efektif dan berhasil dalam meminimalkan gangguan yang bersumber dari adanya konflik serta dapat memberikan solusi yang memuaskan dan dapat diterima (Thakore, 2013).

Penyelesaian suatu masalah ada beberapa cara antara lain integrating, avoiding, obliging, dominating dan compromising (Rahim \& Katz, 2019). Tidak semua manajemen konflik dapat bekerja secara efektif dalam segala situasi. Satu tipe manajemen konflik mungkin dapat efektif dalam mengatasi sebuah situasi, namun dapat berubah menjadi tidak efektif ketika situasi tersebut berubah (Marquis \& Huston, 2019). Pada kesehatan organisasi yakni sekolah, ketidaktepatan penerapan manajemen konflik dapat menyebabkan kondisi kerja yang kurang sehat serta dapat menimbulkan stres pada anggotanya (Chan dkk., 2014; Maged dkk., 2018). Hal ini menunjukkan pentingnya intervensi yang diberikan untuk mengelola konflik khususnya dalam organisasi.

Terdapat beberapa intervensi untuk meningkatkan manajemen konflik yang salah satunya ialah pelatihan emotional intelligence (Başoğul \& Özgür, 2016; Shih \& Susanto, 2010; Zhang dkk., 2015). Emotional intelligence adalah emosi yang saling terkait, kompetensi sosial, keterampilan, dan fasilitator yang dapat menentukan seberapa paham seseorang dalam mengekspresikan dirinya, memahami orang lain, berhubungan dengan orang lain, mengatasi tuntutan, tantangan, dan tekanan dalam sehari-hari (Furnham, 2003). Terdapat lima aspek emotional inteligence yakni intrapersonal, interprsonal, stress management, adaptibility dan general mood (Bar-on, 2014).

Beberapa penelitan menunjukkan bahwa emotional intelligence memiliki hubungan positif dengan manajemen konflik. Individu yang memiliki skor tinggi pada emotional intelligence akan mampu untuk mengembangkan relasi secara positif, memiliki toleransi ketika menghadapi siutasi yang menekan serta dapat mengendalikan perasaan tanpa kehilangan kendali (Vashisht dkk., 2018). Hal ini menunjukkan bahwa individu dengan emotional intelligence yang tinggi cenderung mampu melakukan manajemen konflik dengan baik (Kelly \& Kaminskienè, 2016). Persepsi individu terhadap kemampuannya dalam mengenali emosinya dan emosi orang lain dengan baik sekaligus mampu meregulasi emosi dalam diirnya, akan menjadi hal yang utama bagi individu untuk tenang dan menganalisis permasalahan yang terjadi (Gunkel dkk., 2016). Disinilah emotional intelligence berperan penting dalam menunjukkan dan memilih tipe manajemen konflik yang tepat untuk menghadapi situasi (Singh, 2018; Tagoe \& Quarshie, 2017). Selain itu, emotional intelligence juga membantu pengembangan dari masing-masing aspek manajemen konflik (H. X. Chen dkk., 2019). 
Kebaruan dan keunikan penelitian pengaruh pelatihan emotional intelligence terhadap pengelolaan konflik yaitu dari segi penguraian aspek pengelolaan konflik dan karakteristik subyek penelitian. Pengelolaan konflik yang dibahas pada penelitan ini diuraikan menjadi beberapa aspek yaitu integrating, avoiding, obliging, dominating dan compromising. Hal ini diharapkan dapat memperjelas pengaruh pelatihan emotional intelligence pada bentuk pengelolaan konflik tertentu. Penelitian ini juga menggunakan subyek yang berusia remaja dan tergabung pada sebuah organisasi (OSIS) sehingga bentuk pelatihan dan pengelolaan konflik berfokus pada individu remaja yang tergabung di sebuah organisasi. Berdasarkan atas beberapa penelitian tersebut terlihat adanya hubungan positif antara emotional intelligence dan manajemen konflik. Oleh karena itu pelatihan emotional intelligence penting dilakukan pada remaja anggota OSIS di SMA. Tujuan dari penelitian ini adalah menguji efektivitas pelatihan emotional intelligence terhadap kemampuan manajemen konflik pada remaja anggota OSIS SMA.

\section{METODE}

Partisipan pada penelitian ini ialah sebagian anggota OSIS yang berusia $15-18$ tahun sebanyak 19 orang. Siswa ini merupakan anggota OSIS dari SMA. Pemilihan parsisipan menggunakan purposive sampling. Purposive sampling pada penelitian ini merujuk pada teknik pengambilan sampel sumber data dengan pertimbangan tertentu. Metode penelitian yang digunakan ialah eksperimen dengan tujuan untuk melihat efektivitas pelatihan emotional intelligence dalam meningkatkan manajemen konflik. Penelitian yang dilakukan di salah satu Sekolah Mengah Atas di Surabaya menggunakan one group pretest-postest design. Desain penelitian ini merupakan kegiatan penelitian yang memberikan tes awal (pretest) sebelum diberikan perlakuan, setelah diberikan perlakuan barulah memberikan tes akhir (posttest).

Eksperimen diberikan pada satu kelompok subjek yang pelaksanannya dibagi menjadi dua fase yakni fase asesmen dan fase intervensi (Seniati dkk., 2015). Pada fase asesmen akan dilakukan pengukuran awal sebelum intervensi diberikan (pretest) dan sesudah intervensi diberikan (posttest). Fase asesmen diukur dengan menggunakan alat ukur berupa skala Manajemen Konflik (The Rahim Organizational Inventory-II) dan Emotional intelligence (Bar-On Emotional Quotion Inventory Youth Version). Sedangkan pada fase intervensi, subjek akan diberikan treatment dalam jangka waktu tertentu yang sudah ditentukan. 


\section{Gambar 1. Desain penelitian}
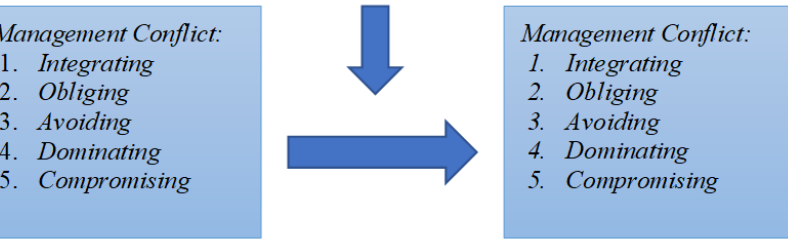

Pelatihan dilakukan dalam kurun waktu dua hari yang dimulai jam 07.00 - 14.00 WIB. Materi yang diberikan mengenai emotional intelligence dan dibawakan oleh peneliti melalui metode lecturing, games, audio visual, discussion, writing task, simulasi, presentasi, studi kasus, refleksi, dan tebak figur. Materi disampaikan melalui enam sesi dan masing-masing sesi berdurasi kurang lebih 90 menit. Berikut ini merupakan gambar urutan pelatihan emotional intelligence.

Tabel 1. Prosedur Pelatihan

\begin{tabular}{|c|c|c|}
\hline Sesi & Aspek & Uraian Kegiatan \\
\hline $\begin{array}{c}\text { I } \\
\text { Who Am I? What } \\
\text { Is My Problem? }\end{array}$ & Management Konflik & $\begin{array}{l}\text { Pada sesi ini peserta diajak untuk mengenali } \\
\text { permasalahan yang dialami oleh remaja, } \\
\text { permasalahan yang ada di organisasi serta } \\
\text { macam-macam manajemen konflik dengan } \\
\text { menggunakna media pemutaran video dan } \\
\text { secara verbal. Kemudian peserta diajak untuk } \\
\text { menganalisis masalah yang ada disekitarnya } \\
\text { serta manajemen konflik yang sering kali } \\
\text { digunakan. Hasil dari analisis tersebut akan } \\
\text { didiskusikan bersama. }\end{array}$ \\
\hline $\begin{array}{c}\text { II } \\
\text { First You Aware, } \\
\text { Than you express }\end{array}$ & Intrapersonal Skill & $\begin{array}{l}\text { Pada sesi ini, peserta diberi penjelasan } \\
\text { mengenai pentingnya menyadari dan } \\
\text { mengenali emosi yang dirasakan dengan } \\
\text { mengunakan video dan verbal. Peserta juga } \\
\text { diajak untuk mengenali kelebihan dan } \\
\text { kelemahan masing-masing dengan } \\
\text { menggunakan metode Johari window. Setelah } \\
\text { itu peserta juga dijelaskna mengenai } \\
\text { pentingnya mengekspresikan emosi secara } \\
\text { tepat. Hal ini dijelaskan dengan verbal dan } \\
\text { permainan. }\end{array}$ \\
\hline $\begin{array}{c}\text { III } \\
\text { The Importance } \\
\text { of Interpersonal } \\
\text { Skills }\end{array}$ & Interpersonal Skill & $\begin{array}{l}\text { Pada sesi ini, peneliti mengajak peserta untuk } \\
\text { memahami perasaan orang lain, } \\
\text { mengidentifikasi dirinya dalam kelompok } \\
\text { sosial, membangun relasi yang positif dengan } \\
\text { cara penjelasan verbal, permainan dan diskusi. }\end{array}$ \\
\hline
\end{tabular}




\begin{tabular}{|c|c|c|}
\hline Sesi & Aspek & Uraian Kegiatan \\
\hline $\begin{array}{c}\text { IV } \\
\text { How to Control } \\
\text { My Self? }\end{array}$ & Stress Management & $\begin{array}{l}\text { Pada sesi ini, peserta diajarkan cara mengelola } \\
\text { dan mengkontrol emosi dengan cara penjelasan, } \\
\text { permainan dan refleksi. }\end{array}$ \\
\hline $\begin{array}{l}\mathrm{V} \\
\text { Be Willing to } \\
\text { Change }\end{array}$ & Adaptability & $\begin{array}{l}\text { Pada sesi ini, peserta diajak untuk melihat sisi } \\
\text { positif dari setiap permasalahan yang ada, cara } \\
\text { bersikap flexible terhadap hal-hal baru di } \\
\text { lingkungan serta mencari solusi yang tepat bagi } \\
\text { setiap permasalan yang ada. Metode yang } \\
\text { digunakan yakni studi kasus, penjelasan verbal, } \\
\text { dan analisis berdasarkan permasalahan yang } \\
\text { ada di sekitar. }\end{array}$ \\
\hline $\begin{array}{l}\text { VI } \\
\text { I'm ready to be a } \\
\text { Better Person }\end{array}$ & General Mood & $\begin{array}{l}\text { Pada sesi penutup, peserta diajak untuk } \\
\text { menonton video dan menerapkan hal-hal yang } \\
\text { telah dipelajari sesuai dengan kasus yang ada di } \\
\text { video. Dilanjutkan peserta diajak untuk } \\
\text { menuliskan berbagai permasalahan nyata yang } \\
\text { ada dan mencoba menerapkan hal-hal yang } \\
\text { telah dipelajari sebelumnya. Di akhir peserta } \\
\text { diajak untuk melakukan afirmasi positf untuk } \\
\text { dirinya. }\end{array}$ \\
\hline
\end{tabular}

Evaluasi pelatihan menggunakan evaluasi sikap yang diukur dengan menggunakan angket manajemen konflik. Pengukuran sikap pada manajemen konflik dilakukan dengan menggunakan alat ukur The Rahim Organizational Inventory-II. Alat ukur ini dikembangkan oleh Rahim (Rahim \& Katz, 2019) dengan tujuan untuk mengetahui strategi seseorang dalam menghadapi konflik yang ditemuinya. Alat ukur yang terdiri dari 28 item yang mencangkup lima macam tipe manajemen konflik yakni integrating, compromising, obliging, dominating dan avoiding. Pengerjaannya menggunakan skala likert (1-5) dengan nilai tertinggi menunjukkan tipe manajemen konflik yang sering digunakan. Analisis data pada pelatihan ini menggunakan program IBM SPSS versi 22. Metode analisis yang digunakan yakni paired sample t-test. Metode ini berfungsi untuk melihat perbedaan keadaan sebelum dan sesudah diberikan pelatihan.

\section{PAPARAN HASIL}

Berikut ini merupakan hasil penelitian yang telah dilakukan. Hasil penelitian ini meliputi hasil pelatihan emotional intelligence untuk meningkatkan manajemen konflik. Pengukuran dilakukan sebelum dan sesudah pelatihan.

Tabel 2. Hasil uji beda manajemen konflik

\begin{tabular}{lcccc}
\hline \multirow{2}{*}{\multicolumn{1}{c}{ Dimensi }} & \multirow{2}{*}{ N } & \multicolumn{2}{c}{ Mean } & \multirow{2}{*}{ Nilai p } \\
\cline { 3 - 4 } Integrating & 19 & 29.3684 & 31.1053 & 0.027 \\
Avoiding & 19 & 19.4737 & 18.7368 & $0.429^{*}$ \\
Dominating & 19 & 20.7895 & 19.3684 & 0.110 \\
Obliging & 19 & 24.2632 & 24.8421 & $0.455^{*}$ \\
Compromising & 19 & 25.7895 & 27.2632 & 0.021 \\
\hline \multicolumn{3}{c}{ *) Signifikan $(\mathrm{p}<0.05)$} &
\end{tabular}


Pada Tabel 2 terdapat dua tipe manajemen konflik yakni integrating dan compromising yang menunjukkan nilai signifikansi kurang dari $0.05(\mathrm{p}<0.05)$ yang berarti adanya perbedaan secara signifikan manajemen konflik dari peserta sebelum dan setelah pelatihan diberikan. Sedangkan ketiga tipe yang lain yakni tipe avoiding, dominating dan obliging memiliki nilai signifikansi lebih dari 0.05 ( $\mathrm{p}>0.05)$ yang menunjukkan tidak memiliki perbedaan yang signifikan manajemen konflik dari peserta sebelum dan setelah pelatihan diberikan. Secara keseluruhan, mean manajemen konflik sebelum dan setelah pelatihan mengalami peningkatan. Hal ini turut mendukung bahwa pelatihan emotional intelligence dapat meningkatkan manajemen konflik pada partisipan. Penelitian ini juga mengukur tiap aspek manajemen konflik. Berikut ini hasil pengukuran dari masing-masing aspek manajemen konflik.

Tabel 3. Norma Skor per Tipe Manajemen Konflik

\begin{tabular}{cc}
\hline Skor & Kategori \\
\hline$>29$ & Sangat Tinggi (ST) \\
$25-29$ & Tinggi (T) \\
$18-24$ & Sedang (S) \\
$13-18$ & Rendah (R) \\
$<13$ & Sangat Rendah (SR) \\
\hline
\end{tabular}

Berdasarkan norma ideal tersebut, berikut adalah gambaran perubahan kategori skor sikap setiap peserta dari pretest ke posttest:

Tabel 4. Skor Total dan Perubahan Manajemen Konflik Tipe Integrating

\begin{tabular}{|c|c|c|c|c|c|c|c|}
\hline \multirow[t]{2}{*}{ No } & \multirow[t]{2}{*}{ Peserta } & \multicolumn{2}{|c|}{ Pretest } & \multicolumn{2}{|c|}{ Posttest } & \multirow[b]{2}{*}{ Selisih } & \multirow[t]{2}{*}{ Keterangan } \\
\hline & & Skor & Kategori & Skor & Kategori & & \\
\hline 1 & $\mathrm{~A}$ & 26 & $\mathrm{~T}$ & 28 & $\mathrm{~T}$ & 2 & Tetap \\
\hline 2 & B & 30 & ST & 27 & $\mathrm{~T}$ & -3 & Turun 1 tingkat \\
\hline 3 & $\mathrm{C}$ & 26 & $\mathrm{~T}$ & 28 & $\mathrm{~T}$ & 2 & Tetap \\
\hline 4 & $\mathrm{D}$ & 28 & $\mathrm{~T}$ & 33 & ST & 5 & Naik 1 tingkat \\
\hline 5 & $\mathrm{E}$ & 27 & $\mathrm{~T}$ & 32 & ST & 5 & Naik 1 tingkat \\
\hline 6 & $\mathrm{~F}$ & 27 & $\mathrm{~T}$ & 34 & ST & 7 & Naik 1 tingkat \\
\hline 7 & G & 29 & $\mathrm{~T}$ & 32 & ST & 3 & Naik 1 tingkat \\
\hline 8 & $\mathrm{H}$ & 28 & $\mathrm{~T}$ & 30 & ST & 2 & Naik 1 tingkat \\
\hline 9 & I & 30 & ST & 28 & $\mathrm{~T}$ & -2 & Turun 1 tingkat \\
\hline 10 & $\mathrm{~J}$ & 34 & ST & 35 & ST & 1 & Tetap \\
\hline 11 & K & 29 & $\mathrm{~T}$ & 34 & ST & 5 & Naik 1 tingkat \\
\hline 12 & $\mathrm{~L}$ & 31 & ST & 29 & $\mathrm{~T}$ & -2 & Turun 1 tingkat \\
\hline 13 & M & 22 & S & 28 & $\mathrm{~T}$ & 6 & Naik 1 tingkat \\
\hline 14 & $\mathrm{~N}$ & 29 & $\mathrm{~T}$ & 28 & $\mathrm{~T}$ & -1 & Tetap \\
\hline 15 & $\mathrm{O}$ & 28 & $\mathrm{~T}$ & 27 & $\mathrm{~T}$ & -1 & Tetap \\
\hline 16 & $\mathrm{P}$ & 32 & ST & 33 & ST & 1 & Tetap \\
\hline 17 & Q & 32 & ST & 35 & ST & 3 & Tetap \\
\hline 18 & $\mathrm{R}$ & 35 & ST & 35 & ST & 0 & Tetap \\
\hline 19 & $\mathrm{~S}$ & 35 & ST & 35 & ST & 0 & Tetap \\
\hline
\end{tabular}


Tabel 5. Skor Total dan Perubahan Manajemen Konflik Tipe Avoiding

\begin{tabular}{|c|c|c|c|c|c|c|c|}
\hline \multirow[t]{2}{*}{ No } & \multirow[t]{2}{*}{ Peserta } & \multicolumn{2}{|c|}{ Pretest } & \multicolumn{2}{|c|}{ Posttest } & \multirow[b]{2}{*}{ Selisih } & \multirow[t]{2}{*}{ Keterangan } \\
\hline & & Skor & Kategori & Skor & Kategori & & \\
\hline 1 & A & 23 & $\mathrm{~S}$ & 29 & $\mathrm{~T}$ & 6 & Naik 1 tingkat \\
\hline 2 & B & 19 & $\mathrm{~S}$ & 15 & $\mathrm{R}$ & -4 & Turun 1 tingkat \\
\hline 3 & $\mathrm{C}$ & 21 & $\mathrm{~S}$ & 17 & $\mathrm{R}$ & -4 & Turun 1 tingkat \\
\hline 4 & $\mathrm{D}$ & 21 & $\mathrm{~S}$ & 19 & $\mathrm{~S}$ & -2 & Tetap \\
\hline 5 & E & 22 & $\mathrm{~S}$ & 19 & $\mathrm{~S}$ & -3 & Tetap \\
\hline 6 & $\mathrm{~F}$ & 22 & $\mathrm{~S}$ & 20 & $\mathrm{~S}$ & -2 & Tetap \\
\hline 7 & G & 22 & $\mathrm{~S}$ & 21 & $\mathrm{~S}$ & -1 & Tetap \\
\hline 8 & $\mathrm{H}$ & 13 & $\mathrm{R}$ & 15 & $\mathrm{R}$ & 2 & Tetap \\
\hline 9 & I & 19 & $\mathrm{~S}$ & 21 & $\mathrm{~S}$ & 2 & Tetap \\
\hline 10 & $\mathrm{~J}$ & 14 & $\mathrm{R}$ & 13 & $\mathrm{R}$ & -1 & Tetap \\
\hline 11 & $\mathrm{~K}$ & 26 & $\mathrm{~T}$ & 19 & $\mathrm{~S}$ & -7 & Turun 1 tingkat \\
\hline 12 & $\mathrm{~L}$ & 29 & $\mathrm{~T}$ & 24 & $\mathrm{~T}$ & -5 & Tetap \\
\hline 13 & M & 22 & $\mathrm{~S}$ & 16 & $\mathrm{R}$ & -6 & Turun 1 tingkat \\
\hline 14 & $\mathrm{~N}$ & 20 & $\mathrm{~S}$ & 19 & $\mathrm{~S}$ & -1 & Tetap \\
\hline 15 & $\mathrm{O}$ & 21 & $\mathrm{~S}$ & 22 & $\mathrm{~S}$ & 1 & Tetap \\
\hline 16 & $\mathrm{P}$ & 14 & $\mathrm{R}$ & 15 & $\mathrm{R}$ & 1 & Tetap \\
\hline 17 & Q & 14 & $\mathrm{R}$ & 13 & $\mathrm{R}$ & -1 & Tetap \\
\hline 18 & $\mathrm{R}$ & 17 & $\mathrm{R}$ & 19 & $\mathrm{~S}$ & 2 & Naik 1 tingkat \\
\hline 19 & $\mathrm{~S}$ & 11 & SR & 20 & $\mathrm{~S}$ & 9 & Naik 2 tingkat \\
\hline
\end{tabular}

Tabel 6. Skor Total dan Perubahan Manajemen Konflik Tipe Dominating

\begin{tabular}{cccccccc}
\cline { 1 - 3 } No & Peserta & \multicolumn{3}{c}{ Pretest } & \multicolumn{2}{c}{ Posttest } & \multirow{2}{*}{ Keterangan } \\
\cline { 3 - 6 } & & Skor & Kategori & Skor & Kategori & Selisih & \\
\hline 1 & A & 18 & R & 16 & R & -2 & Tetap \\
2 & B & 19 & S & 12 & SR & -7 & Turun 2 tingkat \\
3 & C & 21 & S & 24 & T & 3 & Naik 1 tingkat \\
4 & D & 26 & T & 22 & S & -4 & Turun 1 tingkat \\
5 & E & 17 & R & 16 & R & -1 & Tetap \\
6 & F & 18 & R & 17 & R & -1 & Tetap \\
7 & G & 20 & S & 22 & S & 2 & Tetap \\
8 & H & 17 & R & 15 & R & -2 & Tetap \\
9 & I & 16 & R & 20 & S & 4 & Naik 1 tingkat \\
10 & J & 21 & S & 22 & S & 1 & Tetap \\
11 & K & 19 & S & 14 & R & -5 & Turun 1 tingkat \\
12 & L & 23 & S & 21 & S & -2 & Tetap \\
13 & M & 18 & R & 17 & R & -1 & Tetap \\
14 & N & 24 & T & 25 & T & 1 & Tetap \\
15 & O & 19 & S & 16 & R & -3 & Turun 1 tingkat \\
16 & P & 22 & S & 22 & S & 0 & Tetap \\
17 & Q & 27 & T & 21 & S & -6 & Turun 1 tingkat \\
18 & R & 19 & S & 22 & S & 3 & Tetap \\
19 & S & 31 & ST & 24 & T & -7 & Turun 1 tingkat \\
\hline
\end{tabular}


Tabel 7. Skor Total dan Perubahan Manajemen Konflik Tipe Obliging

\begin{tabular}{|c|c|c|c|c|c|c|c|}
\hline \multirow[t]{2}{*}{ No } & \multirow[t]{2}{*}{ Peserta } & \multicolumn{2}{|c|}{ Pretest } & \multicolumn{2}{|c|}{ Posttest } & \multirow[b]{2}{*}{ Selisih } & \multirow[t]{2}{*}{ Keterangan } \\
\hline & & Skor & Kategori & Skor & Kategori & & \\
\hline 1 & $\mathrm{~A}$ & 24 & $\mathrm{~T}$ & 24 & $\mathrm{~T}$ & 0 & Tetap \\
\hline 2 & B & 22 & $S$ & 27 & $\mathrm{~T}$ & 5 & Naik 1 tingkat \\
\hline 3 & $\mathrm{C}$ & 22 & $S$ & 28 & $\mathrm{~T}$ & 6 & Naik 1 tingkat \\
\hline 4 & $\mathrm{D}$ & 23 & $S$ & 25 & $\mathrm{~T}$ & 2 & Naik 1 tingkat \\
\hline 5 & $\mathrm{E}$ & 22 & S & 20 & S & -2 & Tetap \\
\hline 6 & $\mathrm{~F}$ & 30 & ST & 27 & $\mathrm{~T}$ & -3 & Turun 1 tingkat \\
\hline 7 & $\mathrm{G}$ & 25 & $\mathrm{~T}$ & 28 & $\mathrm{~T}$ & 3 & Tetap \\
\hline 8 & $\mathrm{H}$ & 24 & $\mathrm{~T}$ & 25 & $\mathrm{~T}$ & 1 & Tetap \\
\hline 9 & I & 26 & $\mathrm{~T}$ & 26 & $\mathrm{~T}$ & 0 & Tetap \\
\hline 10 & $\mathrm{~J}$ & 20 & S & 26 & $\mathrm{~T}$ & 6 & Naik 1 tingkat \\
\hline 11 & $\mathrm{~K}$ & 26 & $\mathrm{~T}$ & 31 & ST & 5 & Naik 1 tingkat \\
\hline 12 & $\mathrm{~L}$ & 24 & $\mathrm{~T}$ & 19 & $\mathrm{R}$ & -5 & Turun 2 tingkat \\
\hline 13 & M & 24 & $\mathrm{~T}$ & 23 & S & -1 & Turun 1 tingkat \\
\hline 14 & $\mathrm{~N}$ & 23 & $S$ & 26 & $\mathrm{~T}$ & 3 & Naik 1 tingkat \\
\hline 15 & $\mathrm{O}$ & 26 & $\mathrm{~T}$ & 24 & $\mathrm{~T}$ & -2 & Tetap \\
\hline 16 & $\mathrm{P}$ & 22 & S & 21 & S & -1 & Tetap \\
\hline 17 & $\mathrm{Q}$ & 29 & $\mathrm{~T}$ & 28 & $\mathrm{~T}$ & -1 & Tetap \\
\hline 18 & $\mathrm{R}$ & 29 & $\mathrm{~T}$ & 27 & $\mathrm{~T}$ & -2 & Tetap \\
\hline 19 & S & 20 & S & 17 & $\mathrm{R}$ & -3 & Turun 1 tingkat \\
\hline
\end{tabular}

Tabel 8. Skor Total dan Perubahan Manajemen Konflik Tipe Compromising

\begin{tabular}{cccccccc}
\multirow{2}{*}{ No } & Peserta & \multicolumn{2}{c}{ Pretest } & \multicolumn{3}{c}{ Posttest } & Keterangan \\
& & Skor & Kategori & Skor & Kategori & Selisih & \\
\hline 1 & A & 26 & T & 28 & T & 2 & Tetap \\
2 & B & 26 & T & 25 & T & -1 & Tetap \\
3 & C & 26 & T & 27 & T & 1 & Tetap \\
4 & D & 26 & T & 26 & T & 0 & Tetap \\
5 & E & 24 & T & 26 & T & 2 & Tetap \\
6 & F & 21 & S & 30 & ST & 9 & Naik 2 tingkat \\
7 & G & 23 & S & 27 & T & 4 & Naik 1 tingkat \\
8 & H & 23 & S & 24 & T & 1 & Naik 1 tingkat \\
9 & I & 23 & S & 25 & T & 2 & Naik 1 tingkat \\
10 & J & 26 & T & 29 & T & 3 & Tetap \\
11 & K & 24 & T & 29 & T & 5 & Tetap \\
12 & L & 26 & T & 27 & T & 1 & Tetap \\
13 & M & 24 & T & 24 & T & 0 & Tetap \\
14 & N & 29 & T & 28 & T & -1 & Tetap \\
15 & O & 26 & T & 27 & T & 1 & Tetap \\
16 & P & 30 & ST & 31 & ST & 1 & Tetap \\
17 & Q & 27 & T & 26 & T & -1 & Tetap \\
18 & R & 27 & T & 27 & T & 0 & Tetap \\
19 & S & 33 & ST & 32 & ST & -1 & Tetap \\
\hline
\end{tabular}


Hasil dari evaluasi pelatihan ini menunjukkan bahwa pelatihan emotional intelligence yang dilakukan dapat meningkatkan manajemen konflik remaja anggota OSIS SMA. Peningkatan ini dapat terlihat dari pengukuran mean, pretest dan posttest yang diberikan. Pada skor manajemen konflik juga dilakukan uji beda. Hasil uji beda skor manajemen konflik yaitu terdapat perubahan yang signifikan pada tipe integrating dan compromising yakni 0.027 dan 0.021. Pada ketiga style lainnya, seperti dominating, avoiding dan obliging terdapat tidak terdapat perubahan yang signifikan namun secara rata-rata skor terjadi penurunan.

Hasil follow-up yang dilakukan pada 19 partisipan juga mendukung bahwa efek dari pelatihan ini cenderung menetap. Pada tipe manajemen konflik tidak ada perubahan dari seluruh peserta. Hasil pengukuran ini menunjukkan bahwa efek dari pelatihan emotional intelligence untuk meningkatkan manajemen konflik pada partisipan dapat bertahan.

\section{PEMBAHASAN}

Individu yang memiliki skor tinggi pada emotional intelligence akan dapat melakukan kolaborasi atau memilih problem solving yang tepat. Hal ini dapat terjadi karena individu tersebut dapat mengkontrol emosinya dan mengembangkan solusi baru dan kreatif sehingga semua pihak yang terlibat dapat diuntungkan (Schlaerth dkk., 2013; Zhang dkk., 2015). Sebaliknya individu yang tingkat emotional intelligence rendah cenderung bersikap memaksakan kehendaknya atau menghindar ketika menghadapi konflik sehingga konflik tersebut tidak akan selesai (Zhang dkk., 2015).

Hal inilah yang membuat fungsi emotional intelligence berperan penting dalam menentukan perilaku dalam manajemen konflik. Guna menemukan solusi yang baik akan memerlukan kompromi sehingga dibutuhkan kemampuan untuk mengenali dan meregulasi emosi (Schlaerth dkk., 2013). Tingkat ektivitas dan ketepatan dalam manajemen konflik sangat bergantung terhadap kemampuan individu dalam mengelola diri dan menemukan solusi yang konstruktif (Beitler dkk., 2018). Individu yang mampu untuk mengelola emosi dan perasaannya serta dapat memahami perseptif dan emosi orang lain akan mampu untuk mengelola konflik secara konstruktif sehingga berkontribusi dalam menyelesaikan konflik seara tepat (Beitler dkk., 2018; Schlaerth dkk., 2013). Gross dan Guerrero mengemukakan seseorang yang emotional intelligence tinggi cenderung menggunakan manajemen konflik tipe integrating dan compromising dikarenakan tingkat keberhasilan untuk mencapai hasil yang fungsional dan produktif (Zhang dkk., 2015).

Berdasarkan hasil penelitian didapatkan hasil bahwa pelatihan emotional intelligence efektif dalam meningkatkan manejemen konflik pada remaja anggota OSIS SMA. Emotional intelligence berkorelasi positif dengan dua macam tipe manajemen konflik yaitu tipe integrating dan compromising (Shih \& Susanto, 2010). Hasil penelitian lain juga menyatakan bahwa emotional intelligence berkorelasi positif dengan manajemen konflik tipe integrating (Başoğul \& Özgür, 2016). 
Kondisi peningkatan manajemen konflik yang adaptif juga tampak pada penelitian ini. Hasil pelatihan menunjukkan adanya peningkatan rata-rata pengunaan tipe manajemen konflik integrating dan tipe compromising. Individu dengan tipe manajemen konflik tipe integrating cenderung peduli terhadap dirinya dan orang lain sehingga mudah untuk bekerja sama, bersikap asertif, terbuka serta memiliki kemampuan pemecahan masalah yang kreatif (Ensari dkk., 2016). Tipe integrating dapat digunakan dalam permasalahan ringan hingga komplek. Tipe manajemen ini, merupakan tipe yang merangkum masalah yang ada sehingga melihat akar permasalahannya dan membuat solusi alternatif atau membuat komitmen untuk menyelesaikan masalah secara efektif (Vashisht dkk., 2018). Tipe ini juga dapat mengurangi konflik dalam tugas maupun relasi sehingga juga mengurangi stres (Hopkins \& Yonker, 2015).

Peningkatan emotional intelligence akan berdampak signifikan pada peningkatan kemampuan manajemen konflik khususnya tipe compromising (H. X. Chen dkk., 2019). Hasil penelitian tersebut juga sejalan dengan hasil dari pelatihan ini yakni terdapat peningkatan skor pada kemampuan manajemen konflik khususnya tipe compromising setelah terjadi peningkatan pada emotional intelligence. Individu yang memiliki tipe penyelesaian konflik ini cenderung berfokus pada prinsip memberi dan menerima sehingga semua pihak yang terlibat harus kehilangan sesuatu agar mencapai kesepakatan bersama (Başoğul \& Özgür, 2016). Pada tipe ini individu akan menunjukkan kerjasama dan assertiveness (Ensari dkk., 2016).

Pada penelitian ini, terlihat bahwa terjadi perubahan yang signifikan pada dua macam tipe manajemen konflik yaitu tipe integrating dan compromising setelah diberikan pelatihan emotional intelligence. Individu dengan tipe manajemen konflik integrating cenderung asertif, terbuka terhadap pendapat sehingga mampu untuk mencari solusi yang terbaik. Sedangkan pada individu yang tipe manajemen konfliknya compromising cenderung mencari jalan tengah dan bersifat memberi dan menerima. Kedua tipe ini sama-sama mencari solusi yang sama-sama menguntungkan untuk semua pihak yang terlibat (X. H. Chen dkk., 2012) sehingga kedua tipe tersebut cukup adaptif untuk mengelola konflik dan meminimalisasi permasalahan yang muncul dalam organisasi (Shih \& Susanto, 2010; Zhang dkk., 2015).

Penelitian ini juga menunjukkan bahwa pelatihan emotional intelligence bisa membantu menurunkan manajemen konflik tipe dominating. Pada tipe dominating, individu cenderung berfokus pada dirinya dan kurang memperhatikan yang lain sehingga dapat menyebabkan konflik. Individu yang memiliki emotional intelligence tinggi tidak akan mengontrol dan mengabaikan opini orang lain karena dalam proses menyelesaikan masalah semua pihak berdiskusi untuk menemukan solusi yang konstruktif dan dapat diterima oleh kedua belah pihak (Vashisht \& Singh, 2020). Selain itu, individu yang memiliki kemampuan mengendalikan emosi yang baik akan lebih sensitif dan empati terhadap orang lain yang akan membuat individu untuk duduk dan berdiskusi guna menemukan solusi yang terbaik (Posthuma \& Posthuma, 2012). Individu yang memiliki 
pengedalian emosi tinggi juga tidak akan menekan orang lain karena hal tersebut tidak akan membawa keuntungan bagi yang individu yang terlibat (Vashisht \& Singh, 2020).

Hasil penelitian ini tidak meningkatkan mamajemen konflik tipe avoiding dan obliging. Maka dapat disimpulkan bahwa hasil penelitian ini dapat meningkatkan manajemen konflik khususnya tipe integrating dan compromising, bukan tipe avoiding dan obliging. Individu dengan tipe avoiding cenderung bersikap menghindar dari permalahan yang ada. Sedangkan individu dengan tipe obliging cenderung bersikap menuruti kehendak orang lain sehingga kedua gaya penyelesaian masalah tersebut lebih berorientasi menang dalam menjaga hubungan namun dengan cara melepas tujuan yang ideal bagi individu tersebut.

Pada partisipan penelitian, hal tersebut mungkin masih terjadi agar mencapai kesepakatan bersama dan terus bergerak maju (Vashisht \& Singh, 2020). Ashkan (dalam Vashisht \& Singh, 2020) juga menambahkan bahwa individu yang biasanya merasakan ketidakadilan saat berada dalam situasi konflik dan apabila dilanjutkan terus menerus dapat berdampak pada emosi yang semakin terkuras dan konflik tidak akan terselesaikan. Oleh karena itu, individu yang kurang bisa mengelola emosinya akan cenderung tidak mampu berpikir rasional dan tidak akan menemukan jalan keluar atas permasalahan yang ada. Sedangkan orang yang mampu mengendalikan emosi akan dapat berpikir rasional selama diskusi dan dapat menemukan solusi untuk menyelesaikan konflik. Hal inilah yang membuat individu cenderung menggunakan tipe manajemen konflik obliging dan avoiding.

\section{SIMPULAN}

Berdasarkan hasil penelitian yang dilakukan, didapatkan informasi bahwa terdapat pelatihan emotional intelligence efektif untuk meningkatkan pengelolaan konflik pada anggota OSIS SMA. Penelitian ini juga menunjukkan bahwa terdapat peningkatan pada kemampuan pengelolaan konflik, khususnya pada tipe integrating $(\mathrm{p}=0.027)$ dan compromising $(\mathrm{p}=0.021)$. Pelatihan emotional intelligence juga dapat menurunkan pengelolaan konflik tipe dominating. Penemuan tersebut menunjukkan bahwa pelatihan emotional intelligence dapat membantu meningkatkan keterampilan pengelolaan konflik. Melalui penelitian ini juga diketehaui bisa membantu menurunkan manajemen konflik tipe dominating, avoiding dan obliging sehingga dapat dikatakan bahwa penelitian ini cukup efektif untuk meningkatkan manajemen konflik.

\section{SARAN DAN REKOMENDASI}

Adapun beberapa saran yang dapat diberikan yakni: 1) hasil dari penelitian ini merupakan sampel kecil dari salah satu sekolah di Surabaya sehingga untuk penelitian selanjutnya dapat mengunakan sampel yang lebih besar untuk memperkuat hasil penelitian ini; 2) penelitian ini hanya mencangkup emotional intelligence dan manajemen konflik secara umum pada anggota atau staff dari OSIS SMA, diharapkan penelitian selanjutnya dapat mengukur emotional intelligence dan manajemen konflik pada level 
ketua departemen atau koordinator di setiap divisi serta dampaknya terhadap relasi dengan anggotanya; 3) pelatihan ini dilakukan dengan singkat sehingga hasil yang didapatkan hanya berhasil meningkatkan tipe integrating dan compromising serta menurunkan tipe dominating. Pada penelitian selanjutnya bisa lebih ditingkatkan agar lebih bisa menurunkan tipe avoiding dan obliging.

\section{DAFTAR PUSTAKA}

Bar-on, R. (2014). The Bar-On Model of Emotional-Social Intelligence. February 2006.

Başoğul, C., \& Özgür, G. (2016). Role of Emotional Intelligence in Conflict Management Strategies of Nurses. Asian Nursing Research, 10(3), 228-233. https://doi.org/10.1016/j.anr.2016.07.002

Beitler, L. A., Scherer, S., \& Zapf, D. (2018). Interpersonal conflict at work: Age and emotional competence differences in conflict management. Organizational Psychology Review, 8(4), 195-227. https://doi.org/10.1177/2041386618808346

Chan, J. C. Y., Sit, E. N. M., \& Lau, W. M. (2014). Conflict management styles, emotional intelligence and implicit theories of personality of nursing students: A cross-sectional study. Nurse Education Today, 34(6), 934-939. https://doi.org/10.1016/j.nedt.2013.10.012

Chen, H. X., Xu, X., \& Phillips, P. (2019). Emotional intelligence and conflict management styles. International Journal of Organizational Analysis, 27(3), 458470. https://doi.org/10.1108/IJOA-11-2017-1272

Chen, X. H., Zhao, K., Liu, X., \& Wu, D. D. (2012). Improving employees' job satisfaction and innovation performance using conflict management. International Journal of Conflict Management, 23(2), 151-172. https://doi.org/10.1108/10444061211218276

Ensari, N., Camden-Anders, S., \& Schlaerth, A. (2016). Constructive Management and Resolution of Conflict. Encyclopedia of Mental Health: Second Edition, 1, 340349. https://doi.org/10.1016/B978-0-12-397045-9.00217-2

Furnham, A. (2003). Emotional Intelligence. 1920.

Gunkel, M., Schlaegel, C., \& Taras, V. (2016). Cultural values, emotional intelligence, and conflict handling styles: A global study. Journal of World Business, 51(4), 568-585. https://doi.org/10.1016/j.jwb.2016.02.001

Hopkins, M. M., \& Yonker, R. D. (2015). Managing conflict with emotional intelligence: Abilities that make a difference. Journal of Management Development, 34(2), 226-244. https://doi.org/10.1108/JMD-04-2013-0051

Jaworska, N., \& MacQueen, G. (2015). Adolescence as a unique developmental period. Journal of Psychiatry and Neuroscience, 40(5), 291-293. https://doi.org/10.1503/jpn.150268

Kelly, E. J., \& Kaminskienè, N. (2016). Importance of emotional intelligence in 
negotiation and mediation. International Comparative Jurisprudence, 2(1), 5560. https://doi.org/10.1016/j.icj.2016.07.001

Maged, R., Rahman, A. E.-, \& Hazem, E. (2018). Conflict management styles, assertiveness and stress among nursing students. 7(2), 49-59. https://doi.org/10.9790/1959-0702084959

Marquis, B. L., \& Huston, C. J. (2019). Leadership roles and management functions in nursing: Theory and Application (10th ed.). Wolters Kluwer.

Posthuma, R., \& Posthuma, R. A. (2012). Conflict management and emotions. International Journal of Conflict Management, 23(1), 4-5. https://doi.org/10.1108/10444061211210797

Rahim, M. A., \& Katz, J. P. (2019). Forty years of conflict: the effects of gender and generation on conflict-management strategies. International Journal of Conflict Management, 31(1), 1-16. https://doi.org/10.1108/IJCMA-03-2019-0045

Schlaerth, A., Ensari, N., \& Christian, J. (2013). A meta-analytical review of the relationship between emotional intelligence and leaders' constructive conflict management. Group Processes and Intergroup Relations, 16(1), 126-136. https://doi.org/10.1177/1368430212439907

Seniati, L., Yulianto, A., \& Setiadi, B. N. (2015). Psikologi Eksperimen. PT Index.

Shih, H. A., \& Susanto, E. (2010). Conflict management styles, emotional intelligence, and job performance in public organizations. International Journal of Conflict Management, 21(2), 147-168. https://doi.org/10.1108/10444061011037387

Singh, A. (2018). Understanding Emotional Intelligence and its Relation to Job Performance. 8(1), 75-89.

Tagoe, T., \& Quarshie, E. N. B. (2017). The relationship between emotional intelligence and job satisfaction among nurses in Accra. Nursing Open, 4(2), 84-89. https://doi.org/10.1002/nop2.70

Thakore, D. (2013). Conflict and Conflict Management. Journal of Business and Management, 8(6), 7-16.

Vashisht, R., \& Singh, K. (2020). Emotional intelligence and conflict management style of doctors. Annals of Biology, 36(3), 483-488.

Vashisht, R., Singh, K., \& Sharma, S. (2018). Emotional Intelligence and its Relationship with Conflict Management and Occupational Stress: A Meta-Analysis. Pacific Business Review International, 11(4), 30-38.

Zhang, S. J., Chen, Y. Q., \& Sun, H. (2015). Emotional intelligence, conflict management styles, and innovation performance: An empirical study of Chinese employees. International Journal of Conflict Management, 26(4), 450-478. https://doi.org/10.1108/IJCMA-06-2014-0039 